\title{
Article \\ Counter Hegemony of Cultural Art Innovation against Art in Digital Media
}

\author{
I Wayan Sugita ${ }^{1, *(\mathbb{D}}$, Made Setini ${ }^{2, * \mathbb{D}}$ and Yahya Anshori ${ }^{3}$ \\ 1 Faculty of Dharma Acarya, University Hindu Negeri I Gusti Bagus Sugriwa Denpasar, Bali 80236, Indonesia \\ 2 Faculty of Economics and Business, Udayana University, Denpasar, Bali 80361, Indonesia \\ 3 Institute of Health Science (STIKES) Wira Medika, Bali 80239, Indonesia; yanshori@kpapbali.org \\ * Correspondence: wayansugita2@gmail.com (I.W.S.); made.setini@student.unud.ac.id (M.S.)
}

check for

updates

Citation: Sugita, IW.; Setini, M.; Anshori, Y. Counter Hegemony of Cultural Art Innovation against Art in Digital Media. J. Open Innov. Technol. Mark. Complex. 2021, 7, 147. https://doi.org/10.3390/joitmc 7020147

Received: 24 March 2021

Accepted: 24 May 2021

Published: 4 June 2021

Publisher's Note: MDPI stays neutral with regard to jurisdictional claims in published maps and institutional affiliations.

Copyright: (c) 2021 by the authors. Licensee MDPI, Basel, Switzerland. This article is an open access article distributed under the terms and conditions of the Creative Commons Attribution (CC BY) license (https:// creativecommons.org/licenses/by/ $4.0 /)$.

\begin{abstract}
Culture is the most critical thing when driving innovation. This paper aims to discuss the counter-hegemony of Drama Gong against modern entertainment arts today with the dynamics of openness innovation. The research method used is qualitative and uses triangulation analysis. Basic qualitative data were obtained by examining two stories of Drama Gong, namely: (1) Angling Dharma (the 1980s) and (2) Jayaprana (2020). Data were collected through observation, document review, and interviews with artists and art observers of the Drama Gong culture of Bali. Qualitative descriptive analysis was carried out by applying the theory of semiotics and the theory of symbolic interaction. The results showed that to maintain its existence since the 1980s Drama Gong performance art has been revitalized as a form of counter-hegemony to today's modern entertainment arts. The counter-hegemony concerns three things, namely: (1) the innovation of Drama Gong performance art, (2) the application of new technology to support the packaging and performance of the Drama Gong, and (3) efforts to maintain the function of the Drama Gong as a way to teach Balinese culture.
\end{abstract}

Keywords: Drama Gong; hegemony; entertainment; cultural art innovation; digital media

\section{Introduction}

Historically, the forerunner of Drama Gong has been around since the late 1950s, a form of the mixture (hybridity) of Western theater, theatrical, stambul, and Janger (Balinese youth dance) [1,2]. The performance is accompanied by Balinese gamelan, dialogue in mixed Indonesian and Balinese languages, and the performers wear traditional Balinese clothes. Since this performance art is a mixture of traditional and modern, it is referred to as "classical drama" or just "drama" [3,4].

Every year in Bali there is always an art parade from eight districts on the island of Bali [5], and the staging event is held in the center of Denpasar City. The name of the venue is "Art Center," so named because it is the center of art showcasing art from all regions in Bali [6]. Every year Drama Gong is staged at this annual event, with a large audience that fills the performance area that accommodates thousands of people [4].

The dimming of the traditional performing arts of the Drama Gong means the weakening of the inheritance of traditional values by future generations in Bali. From a cultural point of view, the dimming of the Drama Gong life means that one of these traditional performing arts is threatened with extinction. The extinction of the Drama Gong also means the loss of traditional media that can preserve Balinese language and literature [7]. In every Drama Gong performance there are always moral messages, both concerning tattwa (philosophy) and morals (ethics). These messages can be conveyed openly or vulgarly or be wrapped or packaged in satirical language [8]. As time went by, in 1986 Drama Gong began to fade, and even in 1990 the staging of Drama Gong was rare or did not exist [9]. The major changes that have occurred in Bali are influenced by external factors that have brought big changes towards the adoption of technology in daily life in Bali [10]. Meanwhile, the internal factor is the lack of management in the body of the Drama Gong, 
including human resources and marketing [11,12]. There needs to be innovation in the Drama Gong environment-openness of innovation will maintain sustainability $[13,14]$. Around the 2000s the Drama Gong appeared again with a slight innovation, using television and YouTube media, but it did not progress because it was still unable to compete with modern digital entertainment [15].

The entertainment that is currently available, in all forms of digital media, has a hegemonic role over the existence of Drama Gong and other local cultural arts [16]. Technology that is not properly managed will threaten moral degradation and this is what is happening in Indonesia because the younger generation is increasingly leaving the culture inherited by their predecessors. Based on this phenomenon, it can be seen that the decline of dramas such as Drama Gong as a traditional media that can be used as a medium for moral education has attracted the attention of various parties [17-19]. Openness of innovation is very necessary in maintaining the cultural arts of Drama Gong. Innovation in all sectors of Drama Gong management is indeed necessary so that this Balinese folk drama does not perish with the times. Technology can be adopted and utilized as a whole in the art of Drama Gong.

\section{Literature Review}

\subsection{Drama Gong Art and Culture}

Drama Gong is a form of traditional Balinese art which is a combination of drama or play (legend) accompanied by Balinese musical instruments consisting of many musical instruments played together. The public realized that the political tragedy that resulted in the killing of thousands of Balinese people also involved janger performance art which is used as a propaganda tool $[20,21]$.

Balinese people since the tragedy will not dare to show performing arts [22,23]. This condition ultimately has had a major impact on religious ceremonies in Bali which always include performing arts in their implementation. The idea of making a drama show emerged from the youths from Abianbase village, Gianyar regency in Bali under the leadership of Anak Agung Raka Payad. This drama was performed for the first time at an odalan ceremony at Pura Puseh (temple) Gianyar, 24 February 1966. Then a cultural figurehead in Bali named I Gusti Nyoman Bagus Panji declared that the official name was Drama Gong [24]. In a very short time, the Drama Gong became a popular show in public life, from the 1970s to the 1980s [25]. Drama Gong performance is used to raise funds to rebuild art activities in the village. Compared to other traditional Balinese theaters, Drama Gong is seen as more modern in terms of its performance because it is familiar with stories written in the form of scenarios, uses Indonesian in the dialogue, the stage layout resembles a proscenium, it uses the accompaniment of gong kebyar, and it involves several sign elements seen in performances, such as make-up, hairstyles, and clothing (costumes), showing a tendency to be more oriented toward everyday realities [26-29].

The function of Drama Gong in the life of Balinese people has great potential in carrying out the concept of Rwa Binedha (two sides of life). The Drama Gong show clearly shows its black and white character through characters and tragic and comedic situations, and it functions as entertainment as well as a guide for spiritual life [5]. Although it functions as entertainment, it also contains moral messages that refer to Hindu scriptures. In this case the Drama Gsong functions as a reflection on religious values as a continuation of religious ceremonies carried out by Balinese people.

The existence of the performing arts of Drama Gong is very important in the life of the Balinese people. Apart from being part of Balinese cultural identity, Drama Gong has developed into a medium of entertainment (spectacle), as well as a medium for education (guidance) and social criticism. The Drama Gong can be positioned as a teacher and students are identified with the audience representing the community [30]. Drama Gong has also become a medium for social criticism and fairly effective socialization of development [2]. Drama Gong has been used as a medium of communication and information to discuss various social problems in society, including issues of education, economy, health, 
environment, and tourism [31-33]. In addition to entertaining the public, the Drama Story played in the Drama Gong can function as a mediation between messages or information from the public to the government indirectly from the dialogue between players regarding various development issues [34,35].

According to the observations of [36,37] Balinese people are experiencing a product, which tends to adopt a modern, cosmopolitan culture, young people in Bali tend to prefer modern arts and culture, including films, music, and various online games that can be enjoyed through gadgets. Balinese youth prefer to spend their time accessing the internet rather than learning their traditional arts.

\subsection{Hegemony Culture Arts and Technology}

The fourth phase of the industrial revolution 4.0 is now marked by the development of digitalization and automation [38]. Entering the current era of the 4.0 industrial revolution, the Balinese folk art Drama Gong is now increasingly marginalized. Only a small part of Balinese people still take care of it. The rapid development of digital information and communication technology is currently accompanied by the development of modern entertainment arts in the form of music, films, online games, and other digital-based entertainment facilities. This is following Antonio Gramsci's opinion that the media is a battleground between competing ideologies. The media as a space in which various ideologies are represented [39]. The media can be a tool to build a dominant culture and ideology for the interests of the dominant class, as well as a means of struggle for the oppressed to build culture and ideology against [29]. Through audio-visual shows in everyone's hand, modern society is presented with various kinds of entertainment. This may directly or indirectly reduce their attention to traditional types of entertainment, including gong plays. Through audio-visual shows in everyone's hand (gadget), modern society is presented with various kinds of entertainment. In general, it can be said that hegemony is closely related to issues that tend to be political. Such an opinion certainly cannot be blamed because hegemony was initially studied by thinkers in the political field, such as what was done by Lenin and Antonio Gramsci [40].

Civilization and social life from time to time continue to develop dynamically. The development of science, technology, economy, art and politics is an element that determines the dynamics of the development of the community's life. These elements have a strong dominance of the socio-cultural development of society [41]. According to Gramsci's theory, intellectuals in every hegemonic element control the strength of the hegemony element for both individual and group interests, but often these intellectuals are also controlled by the hegemonic power above them. According to Gramsci, usually, the greatest hegemony power is the State. As an ethnic group living in the archipelago, the Balinese have a wealth of unique cultural arts and have made Bali an island that is well known in the eyes of the world. The image of the attraction of foreign tourists to come to Bali is so strong that Bali has developed into a very famous tourist destination not only domestically but also to foreign countries. The holistic linkage of Balinese art and culture between art, customs, religion and ceremonies has provided a special attraction for tourists to come to Bali. This raises concerns about the shift of concept "I am you" (asah asih asuh) live in Bali which is the basis for coexistence [42]. The existence of Drama Gong is a medium in the current era of globalization, the rise of local culture has the opportunity to color national culture, even global culture. The innovation in the Drama Gong is the answer to the hegemonic entertainment of modern art in today's digital era [43].

\subsection{Open Innovation of Culture Arts and Technology}

Cultural Art innovation is formed in an order of norm values, extending curiosity, creativity, and flexibility. There is a diversity of open innovation which requires open trust and norms, responsibility, for the sake of sustainability [44]. Cultural Arts that is innovation-oriented is the main key in emerging the quality of art products, presentation displays, and even included in the innovation business model in the scope of art lovers. The 
environment of art actors can make changes in the art environment by adopting cultured technology. It is even able to become a motivator in changing the characteristics of old cultural arts for the opportunity for growth and sustainability of cultural arts. Dimensions in cultural arts apply local wisdom which always has the concept of togetherness, a high sense of belonging and sharing, maintaining the basic order as a builder of acceptance of new innovations in technology [45].

Cultural arts in Bali are the basis for guiding people's lives in Bali, but since Bali become tourist destination, many cultures will meet and demand that people continue to transform [46]. Technological advances must be adopted, collaborated with arts, for cultural example the Drama Gong art so that it can become public entertainment, to deliver moral messages that maintain the philosophical concept of life in Bali. Art is a performance expression most commonly found in society which has various implied functions [47]. Drama Gong is a folk art that adapts stories from ancient Balinese literature [48]. Over time, many mastered arts were able to replace this show. Some modern societies spend more time in front of gadgets visiting drama venues, but with the persistence and enthusiasm of the players, this event still has a place in the hearts of the audience [49]. According to Yamashita [34] The Drama Gong can be recognized and disseminated to the Indonesian people that this is a performing art from the island of Bali. The hope is that the Indonesian people will realize that there are performances that can collaborate traditional and modern elements. By making photography books, it is hoped that the public will also feel the atmosphere that occurs during the performance so that they want to know more about this event [47].

Gramsci sees the media as a space in which various ideologies are represented [50]. The media can be a tool to build a dominant culture and ideology for the benefit of the dominant class, as well as a means of struggle for the oppressed to build culture and fight ideology. Drama Gong as a traditional communication medium also has a message of wanting to convey ideology or to society because art without a message is meaningless.

\section{Framework Hegemony of Drama Gong}

The various articles above have not specifically discussed the counter-hegemony of Drama Gong to modern entertainment arts, so this study is relevant to be carried out as part of an effort to publish innovations in the performing arts of Drama Gong in facing the challenges of today's modern era. Figure 1 shows the concept of revitalizing the staging of Drama Gong in Technology Innovation.

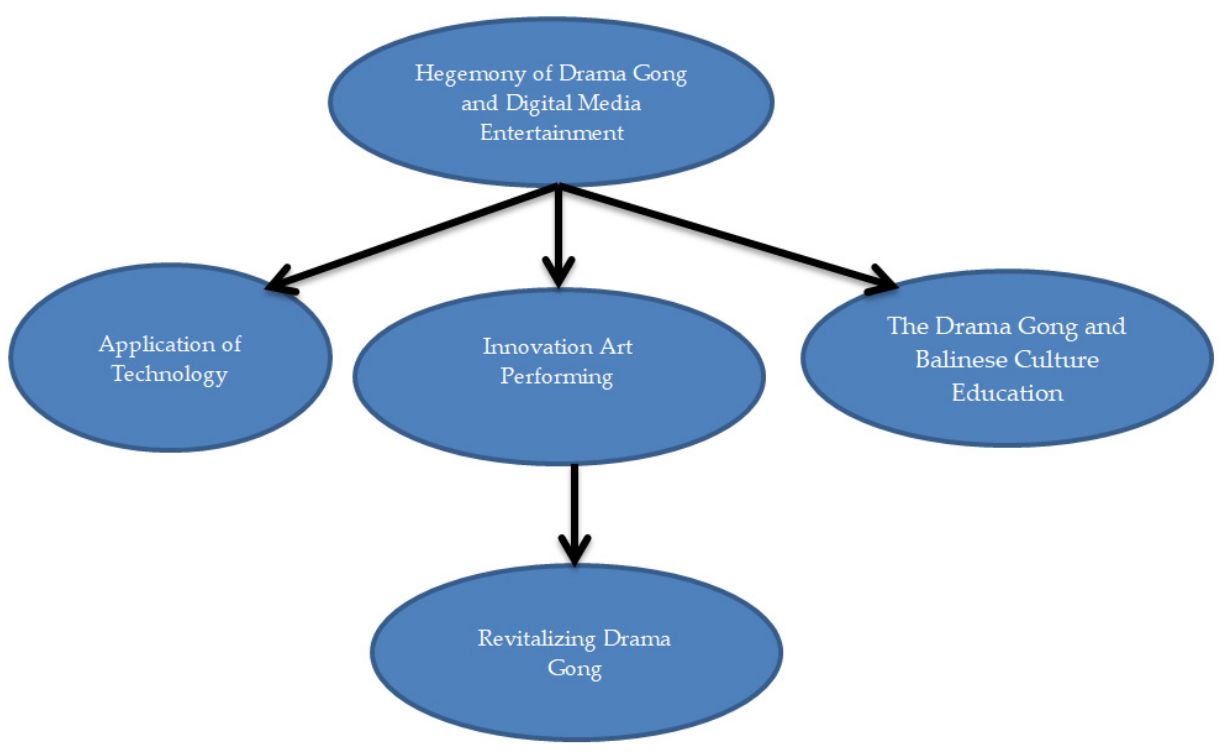

Figure 1. Conceptual Framework for the Innovation of the Performing Arts and Culture Drama Gong. 


\section{Methods}

The method in this research is qualitative research with triangulation analysis techniques. Triangulation method is essentially a multi method approach that researchers take when collecting and analyzing data [51]. Efforts to check the correctness of data or information obtained by researchers from different points of view by reducing as much as possible the bias that occurs during collection and analysis. The samples used in this study were 3 actors who understand and relate to the Drama Gong artwork, namely Drama Gong observers, Drama Gong performers and Drama Gong viewers. Acquisition of data obtained by observation, interviews and surveys. Direct interviews were conducted by research and direct observation into the field. Interviews were conducted with three sources to ensure that the answers they provide have the same answers so that the validity and reliability of the data can be trusted. This scientific work aims to discuss the innovation of Drama Gong in Denpasar City, and Gianyar Regency as an effort to counter-hegemony towards modern entertainment arts such as films, music, and online games in today's digital media. As a result of a qualitative study, basic data were obtained by examining four stories of Drama Gongs recorded on videos, CDs, and YouTube in the 1980s-2000. Two-story Drama Gong namely: (1) Angling Dharma from Bintang East Bali, Denpasar Group (the 1980s), and (2) Jayaprana from Sanggar Kayon, Pejeng Gianyar (2020) recorded in Video, the CD year 1980-the 1990s and YouTube have been arguing (a) represents his time, (b) there are variations of the story and representation sekaha (group) Drama Gong, and (c) the authors involved in the performance, and (d) there is Balinese cultural education delivered by the clowns, in addition to the core message contained in each story (story) of the show.

Data used as material for this paper were also obtained from reading material related to the topics discussed, as well as through engaging observations (observation Participatory) of the performing arts of Drama Gong in 2020 with Jayaprana who is currently playing produced by Bali TV, where the writer is involved as one of the players, as well as indepth interviews with key informants, namely observers of Balinese arts and culture and representatives of loyal audiences of Drama Gongs in Denpasar City, Gianyar Regency, and Bangli Regency.

The data obtained were analyzed by applying the theory of semiotics and the theory of interaction symbolism. Semiotics is a theory of signs [52,53]. The content of the dialogue, the scene, the appearance of the Drama Gong are signs to be translated further in this study. Furthermore, to understand the audience's response to the Drama Gong performance, the theory of symbolic interactionism is applied. The essence of the theory of interactionism is that human interactions with each other are influenced by certain symbols [54], including the content of the dialogue, the scenes in the drama that affect the thoughts and actions of the audience.

\section{Result}

\subsection{Hegemony of Drama Gong and Digital Media Entertainment}

The fourth phase of the industrial revolution (4.0) is now marked by the development of digitalization and automation, which is a combination of the internet and manufacturing. The process that occurs is the social and cultural changes that occur rapidly, the basic concerns basic need and desire community. The basis for this change is the fulfillment of our desires for the fulfillment of human needs quickly and with quality. Therefore, in the era of the industrial revolution, many have changed the way humans work from manual use to automation or digitization [55].

The onslaught of globalization in this digital era, among others, is in the form of the increasing number of modern arts and culture (entertainment media) that came together with the 4.0 era in the midst of Balinese people's lives, directly or indirectly, marginalizing the existence of the Drama Gong performance. The existence of the Drama Gong has been hegemonies by a variety of modern entertainment, including music, films, and online games, efforts to rescue and revitalize the Drama Gong need to be done considering that this art performance have become part of the cultural identity of the Hindu community in 
Bali [39]. In the current era of globalization, local culture actually has the opportunity to rise to color national culture, even global culture [40].

To maintain the performing arts of the Drama Gong, several Balinese Drama Gong groups, especially in some areas such as Denpasar City, Gianyar Regency, and Bangli Regency, have made improvements so that their Drama Gong groups can still live and exist [1]. Efforts to maintain the performing arts of the Drama Gong are also a form of counter-hegemony against modern cultural arts such as music, films and online games available on this digital media [2]. According to [41], counter-hegemony is a resistance to the dominant culture. The rise of art and the performance of Drama Gong is a dominant form of culture in the era of the industrial revolution today. The counter-hegemony is manifested in at least three things, namely the innovation of the Drama Gong performance, the application of new technology, and efforts to maintain the function of the Drama Gong as Balinese cultural education [53].

\subsection{Open Innovation Art Performing}

By demands of the times, Drama Gong has undergone an intensive process of innovation since the early 1980s, when the development of video recording technology, CDs, and the growth of TV channels in Indonesia. Several Drama Gong arts groups, namely: Bintang Bali Timur, Denpasar, Gong Wira Bhuwana and Sanggar Kayon, Gianyar, and Sancaya Dwipa Milenium, Bangli continue to innovate their Drama Gong performances. In general, the innovation of Drama Gong includes several aspects, including aspects of story packaging, dialogue, player regeneration, stage settings, and collaboration with other artists in Table 1.

Table 1. The Open Innovation of Drama Gong performance at post-1980s.

\begin{tabular}{|c|c|c|c|}
\hline \multirow{2}{*}{ No } & \multirow{2}{*}{ Aspect } & \multicolumn{2}{|r|}{ Description } \\
\hline & & 1950-and-1980s & Post-1980s \\
\hline 1 & $\begin{array}{l}\text { Open mindset of players } \\
\text { in the era of desruption }\end{array}$ & $\begin{array}{l}\text { Internal Innovation } \\
\text { Traditional staging technology }\end{array}$ & \multirow{3}{*}{$\begin{array}{c}\text { Drama Gong players must be open and accept the reality } \\
\text { of the changing order of society in today's digital era. } \\
\text { Mastery in english is needed so that the Drama Gong } \\
\text { players are able to convey educational messages to } \\
\text { non-Balinese audiences (foreign tourists). } \\
\text { Balinese folk tales which shown and created according to } \\
\text { present creation, and long time duration of drama gong } \\
\text { managed accordingly to several episode to adjust time } \\
\text { shown in tv and YouTube. }\end{array}$} \\
\hline 2 & $\begin{array}{l}\text { Capacity building for } \\
\text { mastery of English }\end{array}$ & Traditional staging Technology & \\
\hline 3 & Packaging Story & $\begin{array}{l}\text { Legends, pennants, folk tales Balinese and, there } \\
\text { is always equipped with a synopsis }\end{array}$ & \\
\hline 4 & Dialogue & Using a single language, namely English Bali & $\begin{array}{c}\text { Contents dialog contemporary by using three languages } \\
\text { (Balinese, Indonesian, English). }\end{array}$ \\
\hline 5 & regeneration Player & dominated by old players & $\begin{array}{l}\text { Includes millennial players. } \\
\text { Staged inside and outside the building (outdoors) }\end{array}$ \\
\hline 6 & settings/settings Stage & Staged inside the building & $\begin{array}{l}\text { supported by stage technology applications (reflectors } \\
\text { light), technical editing, and so on. }\end{array}$ \\
\hline \multicolumn{4}{|c|}{ External Innovation } \\
\hline 1 & $\begin{array}{l}\text { Collaboration with } \\
\text { other arts }\end{array}$ & Only Drama Gong players & $\begin{array}{l}\text { - Open innovation is also carried out in collabora- } \\
\text { tion with other artists, including Balinese pop mu- } \\
\text { sicians, comedy, dangdut pop, bebondresan, and } \\
\text { other arts. }\end{array}$ \\
\hline 2 & $\begin{array}{l}\text { Digital product } \\
\text { packaging techniques }\end{array}$ & $\begin{array}{l}\text { Traditional staging Technology, or the } \\
\text { performance of Drama Gong in one big stage } \\
\text { directly in front of the audience. }\end{array}$ & $\begin{array}{l}\text { - Product packaging with a time duration arranged } \\
\text { in such a series according to the allocation of broad- } \\
\text { cast time (on TV or YouTube). } \\
\text { Drama Gong products are packaged in the form of } \\
\text { a CD or MP4 file. }\end{array}$ \\
\hline 3 & $\begin{array}{l}\text { Techniques for digital } \\
\text { product distribution }\end{array}$ & $\begin{array}{l}\text { Not through the media of technology as } \\
\text { mediation for the delivery of the entertainment } \\
\text { of Drama Gong, but it is shown directly facing } \\
\text { the audience. The audience can interact directly } \\
\text { with the Drama Gong cultural arts performers }\end{array}$ & $\begin{array}{l}\text { - Channeled through direct and indirect perfor- } \\
\text { mances (CD, TV, online broadcast/YouTube). }\end{array}$ \\
\hline
\end{tabular}


Table 1 shows innovations in the performing arts of Drama Gong after the 1980s, both internal and external. Internal innovation is carried out by:

First, the existence of an open mindset of players from the Drama Gong in the current era of disruption. They must be aware of the changes in the order of life in society in today's digital era.

Second, there is an increase in the capacity of the Drama Gong players. Additionally, they are required to understand the performance material, Drama Gong players are required to master English, so that they are able to convey educational messages to non-Balinese audiences (foreign tourists).

Third, there is the packaging of the story (lelampahan) of the Drama Gong. The new play performed by the Drama Gong differs than the traditional theater which the creator does not know [56-59]. The era of the Industrial Revolution 4.0 which was marked by the development of digital technology, was written as the basis for the performance of the Drama Gong to be seen as increasingly important for its duration, both through the online TV channel Drama Gong broadcast on YouTube [60-63]. To add variety, the Drama Gong story can be taken from the legendary story (Mahabharata, Panji Malat) or some Indonesian folk tales such as "Keong Mas, Ande-ande Lumut, and Golek Kencana". The story told by the Drama Gong performance and Balinese traditional arts is imbued with the principle of balance (rwa bhineda) or harmony between good and bad, two different forces, positive-negative, top-down, good-bad, mutually and mutually need.

Fourth, innovation in terms of contemporary dialogue by using Indonesian and English as a distraction, in addition to Balinese as the main performance language. In the 2020 version of the Jayaprana story, this was shown, among others, in the dialogue of the clerks who were accompanying the governor of Sawunggaling who delivered education related to preventing the transmission of Covid19. At the time when the scene came out of the bathroom, the clerk stated that "to wash hands" or washing hands is important, besides wear a mask and keep your distance (social distancing) to avoid Covid19.

Fifth, there is a regeneration of Drama Gong players by including millennial generation players. In cultivating the Jayaprana story produced by Bali TV, the Balinese young generation is deliberately played more actively, both as players, make-up, choreography sections, and other supporting crews. The involvement of these young players is also to ensure that there is a process of art-cultural inheritance to the next generation. The Drama Gong is presented in a new style that can captivate the millennial generation. In addition to involving the millennial generation, the packaging of this new model of Drama Gong is an effort to save this art performance so that it continues to exist coloring Balinese cultural arts. This Drama Gong innovation is also a form of counter-hegemony to the existence of entertainment (including online games virtual world) which is now more loved by young people in Bali. Through traditional art shows, including Drama Gong on TV and YouTube, it is hoped that Balinese young people can get to know the cultural traditions of their ancestors [64,65].

Sixth, the setting stage of the Jayaprana story (a very kind young Balinese man) produced by Bali TV (2020) is deliberately set up inside the building and outside the building (open nature) by taking the background in a palace/castle in Bali, as a soap opera so that the atmosphere is more lively and more challenging. The presentation of the story with scenes per episode, with more mature management, involves many IT experts. The shooting of the Drama Gong in the open is certainly supported by the Bali TV creative team. The existence of a creative team is very vital both in the process of preparing and implementing the Drama Gong performances and in the packaging of the shows. The team creative manages the plays that need to be performed, manages the make-up, the clothes of the players, the selection of the shooting location, as well as the timing and schedule for the drama. The creative team also manages the duration of the performance and the packaging of the Drama Gong, both on CD recordings that can be played via video or broadcast on TV and channels YouTube. 
In addition to some of the internal innovations mentioned above, the new version of the Drama Gong is also conducting open innovation, accepting elements from outside for further refinement of its appearance. This open innovation includes several things.

First, Collaboration with other artists in the performance of an innovative version of the Drama Gong which has been in process since the 1990s has been enriched with various modern arts, such as the improvisation of dangdut songs, comedy elements, and the need to collaborate with other arts that can boost the existence of Drama Gong, as in its heyday and the performance of the Drama Gong was also coupled with other arts that happened to have a rising reputation. The Drama Gong in the 1990s era was also combined with performances of Balinese pop songs and comedy, bebondresan and jogged dance (Balinese dance of female dancers inviting men to the stage) witnessed in the Drama Gong Pengamen, which was performed in 2000 accompanied by Indonesian-language dangdut songs accompanied by a keyboard or piano, not a traditional gamelan.

Second, external innovation is also carried out in the packaging of the Drama Gong art product. In addition to managing art products with such time durations in a serial manner according to their broadcast time allocation (on TV or YouTube), Drama Gong art products are deliberately packaged in CD or MP4 files to be marketed to the public.

Third, external innovation is also carried out in the distribution of the Drama Gong art product. Performance media do not only rely on live shows that can be watched by audiences but have utilized digital technology, both through television broadcast channels and YouTube channels and Drama Gong has been uploaded on the YouTube network with the long and short duration to be able to display shows that are in line with expectations the audience. The use of digital technology in the form of YouTube in the era of the Industrial Revolution 4.0 has now become a demand so that the Drama Gong performance art can be spread more widely [64]. Technology makes Drama Gong performances not only watched by Balinese people on the Island of the Gods but can be watched by people throughout corners of the world [5].

\subsection{Open Innovation Application of Technology}

The efforts to revitalize the Drama Gong are supported by the application of the most updated technology. Technology applications are needed to support staging on sound systems and LCD devices, packaging and distribution of the performance arts of the Drama Gong in the form of recordings on CD, TV shows, and YouTube. Entering the era of the Industrial Revolution 4.0, the ability to adapt and transform is an important factor that artists must have because information and communication technology is the core of every aspect of the creative process that artists adopt [66].

After the 1990s, TV developed, accompanied by digital media/cyberspace in the form of YouTube in the era of the industrial revolution 4.0. The Balinese millennial generation is more likely to become consumers of digital entertainment, online games, at the same time they are leaving traditional arts, including Drama Gongs, because the packaging is less attractive. With the open innovation of the Jayaprana story Drama Gong on Bali TV (2020) some Balinese young people return to liking the Drama Gong performance art inherited from their ancestors. The results of interviews with three Drama Gong actors, namely art observers, performers and Drama Gong viewers regarding the packaging of Drama Gong.

Drama Gong is a fan of many circles, there are several plays or stories that have become legends and stick to the hearts of the people, for example, Punakawan's story is funny and amusing. The message conveyed through the players is not only funny to see but full of moral messages, including about how to develop areas in Bali. The message about the vision of the development of today's Balinese leaders, namely Sat kerthi Loka Bali, who wants to strengthen traditions in Bali. Preservation of Drama Gong is important so that millennials do not always play games so that with the innovation of Drama Gong, it becomes a show through TV and YouTube that is very popular with young people

(Prof. Dr. I Wayan Dibia, Wayan Sugita, Juni Ambara, interview, 10 November 2020). 
The Drama Gong is an alternative spectacle of Balinese cultural arts that can be enjoyed by Balinese people and young people through television or YouTube. The packaging of Drama Gong performances with technological means makes the return of this art favored by millennial so that this is a form of counter-hegemony against the dominance of modern entertainment arts so that young Balinese as the next generation do not get more immersed in the hedonist and capitalistic culture brought by online digital media.

\subsection{The Drama Gong and Balinese Culture Education}

According to [6] the counter-hegemony of Drama Gong to modern entertainment media entertainment today is also reflected in the development of Drama Gongs as a medium for cultural education to strengthen ethnic identity and the continuity of the cultural traditions of the Balinese Hindu community. Through the Drama Gong the traditional values of the Balinese Hindu community can be maintained [67]. There are several educational messages about the Drama Gong culture that are often conveyed in Drama Gong performances [63].

First, education on the importance of the Tri Hita Karana philosophy [68], namely the three basic teachings of Balinese Hinduism, namely human efforts to establish a harmonious relationship with God (parahyangan), maintaining a harmonious relationship with each other (pawongan), and maintaining harmony in life with the environment (palemahan).

Second, related to efforts to harmonize relationships between humans, the Drama Gong also has a role in preserving the Balinese language. The cultural treasures of the Balinese Hindu community will remain steady, sustainable as long as they can maintain the existence of the Balinese language [69]. The Balinese language could disappear on the face of the earth in 2041 if the Balinese young generation did not use the Balinese language [50]. So that the effort to develop the Balinese language becomes important, among others, the material for coaching the Balinese language in the Drama Gong is about the Balinese language sor-singgih. Sor-singgih Balinese language is for the norm of politeness [30]. In the development of the Balinese language, it is also related to the social stratification of the Balinese people. The description of the social stratification of the Balinese Hindu community is shown in the dialogue of the rulers, namely the governor of Sawonggaling and his clerks in the following Jayaprana story in 2000.

"Uduh, cai parekan bena ajak dadua, sayaga cai, bena lakar ke alase, ngatehang I Nyoman Jayaprana." It means "Hi, my servants, get ready, I will go to the forest to escort I Nyoman Jayaprana".

"Inggih Ratu Gusti patih, Durusang Mamargi, Titiang Sampun sayaga jagi ngiring Pamargin gusti". This means yes gusti patih, after you, I am ready to accompany Gusti on the journey, escorting Nyoman Jayaprana to the middle of the forest.

Third, Drama Gong also conveys social criticism, delivered by players of Drama Gong clowns about issues related to health, education, the environment in the life of Balinese cultural tourism. The social criticism of the Drama Gong also highlights social inequalities that cause social anxiety, where humor is needed to accommodate aspirations that are not officially voiced by comedians or Drama Gong performers. Humor is deliberately presented as a satire, criticism of the imbalance that occurs is also packaged a little satire, ridicule, jokes, and protests are expressions of oppression, from a condition of powerlessness [70]. The social criticism of the Drama Gong is conveyed persuasively, does not directly attack the person but can effectively raise awareness of the despicable nature of arrogance, greed, human selfishness and the arbitrariness of the authorities, such as the story of "Jayaprana" on Bali television in 2020 [40].

Fourth, the Drama Gong cultural education is also enriched with messages on Balinese local development. The Bali TV drama series in the year 2020, specifically discusses the vision of the Bali Provincial Government "Nangun Sat Kerti Loka Bali". The vision is intended to lead to a New Era of Bali, which is an era marked by a new life order. This vision is translated through a pattern of overall development plans, which implies maintaining the 
sanctity and harmony of Bali and its contents to create the life manners of Bali as Prosperous. the principle of Trisakti Bung Karno that is sovereign in Politics, economically independent, and with a cultural personality through development in a patterned, comprehensive, planned, directed, and integrated manner within the framework of the Unitary State of the Republic of Indonesia based on the Pancasila Values of 1 June 1945 [71].

The presentation of a classic story in Drama Gong performance that has a symbolic content to be conveyed to the public. In accordance with theory of symbolic interactionism [68], along with technological advances, Drama Gong has made innovations so that the language used can be understood by the audience. The educational material for Drama Gong is communicative enough to be used. The awareness and participation of the audience. In order not to disappear by the times, the effort to revitalize the Drama Gong according to the latest technological developments needs to be done considering that this art performance has become part of the cultural identity of the Hindu community in Bali $[39,69]$. This revitalization is carried out by rearranging the plays shown, professional management, clothing arrangements, dialogues and acting, timing and lighting, by involving the millennial generation in Table 1.

Developing creative ideas that can read the tastes of the audience at any time or providing information about issues that are currently popular by utilizing digital technology is a media discourse as well as a cultural practice for the audience [72]. Drama Gong has given cultural meaning oriented to creative and modern thoughts but still based on positive traditions that reflect the personality of the national culture [73]. From an existentialism perspective, the Drama Gong is essentially a basic problem of human life as a vehicle for maintaining cultural values in Bali that should be inherited by the younger generation.

\section{Conclusions}

Drama Gong is a Balinese folk art performance that was born in the late 1950s. The technology era shifted the Drama Gong to become a favorite spectacle for the Balinese people because it was shifted by other entertainment media [74]. To maintain its existence and revitalize Drama Gong, several Drama Gong groups in the city of Bali since the early 1980s have taken steps to revitalize the performance of Drama Gong. The revitalization of Drama Gong is carried out as a form of counter-hegemony towards today's modern entertainment [75]. The counter-hegemony is manifested in at least three things, namely (1) innovation in Drama Gong performance which involves packaging story themes, clothing (costumes), various dialogues, involvement of millennial players, and set/stage performances supported by digital technology; (2) application of new technology to support the packaging and performances of Drama Gong in the form of TV and YouTube shows; and (3) efforts to maintain the function of Drama Gong as Balinese cultural education to strengthen ethnic identity and the continuity of the cultural traditions of the people in Bali. Following the revitalization of Drama Gong according to the times that involve the young generation of Bali must always be able to develop sustainable innovation. Open Innovation Drama Gong must be done internally and externally by always sharing knowledge. This open innovation increases the marketing strategy sector for Drama Gong which is also needed so that the broadcast of Drama Gong through digital media channels, television, or YouTube can be known by all generations across countries [76]. The openness of innovation both internally and externally is expected to bring positive changes in the preservation of cultural arts so that the openness of innovation in the art of Drama Gong, provides sustainability for this art. Internal and external innovation can bring sustainability in the arts and culture sector [77]

Author Contributions: Conceptualization, methodology, I.W.S. and M.S.; validation, formal analysis, investigation, resources, I.W.S. and M.S.; writing - review and editing, M.S. visualization, supervision, project administration, acquisition, M.S., I.W.S. and Y.A. All authors co-operated in completing this. All authors have read and agreed to the published version of the manuscript.

Funding: This research received no external funding. 
Institutional Review Board Statement: The study was conducted in accordance with the guidelines of the Declaration of Helsinki, and approved by the Institutional Review Board.

Informed Consent Statement: Approval of action obtained from all objects involved in the research.

Data Availability Statement: Data available upon request.

Acknowledgments: Very grateful to, observers of Cultural Arts in Bali (I Wayan Dibia), the performers of Drama Gong Culture, and the audience who have helped provide the information needed for this research.

Conflicts of Interest: The authors declare no conflict of interest.

\section{References}

1. Tisnu, T.R. Balinese Folk Theater Drama Gong. Scientific Oration at the XXIV Anniversary of the Indonesian Arts College Denpasar. 1996. Available online: https:/ / www.balipost.com/news/2020/06/25/131825/Drama-Gong,Teater-yang-Elegan.html (accessed on 1 June 2021).

2. Sugita, I.W. Drama Gong as Educational Media and Social Criticism. J. Bali Stud. 2020, 10, 557-578.

3. Putra, I.N.D. Modern performing arts as a reflection of changing Balinese identity. Indones. Malay World 2008, 36, 87-114. [CrossRef]

4. Putra, I.N.D. Kidung Interaktif: Vocalising and interpreting traditional literature through electronic mass media in Bali. Indones. Malay World 2009, 37, 249-276. [CrossRef]

5. Dibia, I.W.; Ballinger, R. Balinese Dance, Drama \& Music: A Guide to the Performing Arts of Bali; Tuttle Publishing: Clarendon, VT, USA, 2012.

6. Covarrubias, M. Island of Bali; Tuttle Publishing: Clarendon, VT, USA, 2015.

7. Hood, M.M. Gamelan Gong Gede: Negotiating Musical Diversity in Bali's Highlands. Musicol. Aust. 2010, 32, 69-93. [CrossRef]

8. Eiseman, F.B. Bali: Sekala E Niskala: Essays on Religion, Ritual, and Art; Tuttle Publishing: Clarendon, VT, USA, 2011.

9. Tenzer, M. Gamelan Gong Kebyar: The Art of Twentieth-Century Balinese Music; University of Chicago Press: Chicago, IL, USA, 2000.

10. Facer, K. Learning Futures: Education, Technology and Social Change; Taylor \& Francis: Abingdon, UK, 2011.

11. Westerman, G.; Bonnet, D.; McAfee, A. Leading Digital: Turning Technology into Business Transformation; Harvard Business Press: Boston, MA, USA, 2014.

12. Du Cros, H.; McKercher, B. Cultural Tourism; Routledge: London, UK, 2020.

13. Robbins, P. From design thinking to art thinking with an open innovation perspective-A case study of how art thinking rescued a cultural institution in Dublin. J. Open Innov. Technol. Mark. Complex. 2018, 4, 57. [CrossRef]

14. Yan, M.R.; Chi, H.L.; Yang, J.Y.; Chien, K.M. towards a City-Based Cultural Ecosystem Service Innovation Framework as Improved Public-Private-Partnership Model-A Case Study of Kaohsiung Dome. J. Open Innov. Technol. Mark. Complex. 2019, 5, 85. [CrossRef]

15. Setiawan, I.N.A.F.; Noorwatha, I.K.D.; Udayana, A.A.G.B.; Wasista, I.P.U.; Jayanegara, I.N.; Aditama, P.W.; Yusa, I.M.M. Kapita Selekta Citraleka Desain 2020: Dialektika Seni, Desain, dan Kebudayaan Pada Era Revolusi Industri 4.0; STMIK STIKOM Indonesia: Denpasar, Indonesia, 2020.

16. Salam, A. The Hoax Phenomenon in Indonesian Society: Observing Anti-Diversity Memes since 2014. Humaniora 2018, 30, 315. [CrossRef]

17. Yuniawan, T. Ecolinguistic study of conservation news texts in Indonesian mass media. Int. J. Humanit. Stud. (IJHS) 2018, 1, 163-183. [CrossRef]

18. Mudana, I.G.; Suamba, I.B.P.; Putra, I.M.A.; Ardini, N.W. Practices of Bali tourism development, threefolding, and Tri Hita Karana local knowledge in new order Indonesia. J. Phys. Conf. Ser. 2018, 953, 012108. [CrossRef]

19. Suwija, I. Nyoman. Identification of anggah-ungguh kruna Balinese language. Int. J. Linguist. Lit. Cult. 2017, 3, 14-21. [CrossRef]

20. Kessler, E.J.; Hansen, C.; Shepard, R.N. Tonal schemata in the perception of music in Bali and in the West. Music Percept. 1984, 2, 131-165. [CrossRef]

21. Putra, D.A.R.M.A. Getting organized; Culture and nationalism in Bali, 1959-1965. In Heirs to World Culture; Being Indonesian 1950-1965; Udayana University Press: Denpasar, Bali, 2012.

22. Putri, G.C. Art for Peace: Grassroots Reconciliation Efforts after the 1965 Tragedy. Indones. Soc. 2020, 48-59. [CrossRef]

23. Putra, I.N.D. The Development of Theater in Bali through the Figure of the Dramawan Abu Bakar. J. Bali Stud. 2016, 3. Available online: https:/ / ojs.unud.ac.id/index.php/kajianbali/article/view/15700 (accessed on 21 March 2019).

24. McGraw, A.C. The political economy of the performing arts in contemporary Bali. Indones. Malay World. 2009, 37, 299-325. [CrossRef]

25. Wiebe, D. Performing Christian Kebalian: Balinese Music and Dance as Interreligious Drama. In Between Harmony and Discrimination: Negotiating Religious Identities within Majority-Minority Relationships in Bali and Lombok; Brill: Leiden, The Netherlands, 2014; pp. 221-243.

26. Straubhaar, J.D. Beyond media imperialism: Assymetrical interdependence and cultural proximity. Crit. Stud. Media Commun. 1992, 8, 39-59. [CrossRef] 
27. Meitridwiastiti, A.A.A. Aspek Sosial Teks Drama Gong Larasati Karya: Ketut Putru. In Seminar Nasional Bahasa, Sastra, dan PengajarannyaSemin; Fakultas Bahasa dan Seni: Singaraja, Indonesia, 2018; Volume 5, pp. 152-161.

28. Widagama, N.P.G. Performance of the Drama Gong “Wijaya Kusuma” as a Communication Media in Abianbase Village, Gianyar District, Gianyar Regency. J. Penelit. Agama Hindu 2017, 1, 545-551.

29. Ardhana, I.K. State and Society: Indigenous Practices in Ritual and Religious Activities of Bali Hinduism in Bali-Indonesia. Int. J. Interrelig. Intercult. Stud. 2020, 3, 20-26. [CrossRef]

30. Oke, A.; Fernandes, F.A.P. Innovations in teaching and learning: Exploring the perceptions of the education sector on the 4th industrial revolution (4IR). J. Open Innov. Technol. Mark. Complex. 2020, 6, 31. [CrossRef]

31. Sarpani, S. Wayang Art as a Medium for Religious Harmony: Analysis of Religious Harmony in the Community of Tunjungharjo Village, Tegowanu District, Grobogan Regency; UIN Walisongo: Semarang, Indonesia, 2018.

32. Rohmah, I.N.K. The Meaning of the Moral Message in the Film "How Funny this Country Is": Charles Sanders Peirce's Semiotic Analysis; UIN Sunan Ampel Surabaya: Jawa Timur, Indonesia, 2019.

33. Shavit, D. Bali and the Tourist Industry: A History, 1906-1942; McFarland: California, CA, USA, 2019.

34. Sudirga, I.K. Innovation and Change in Approaches to Balinese Gamelan Composition. Malays. J. Music 2020, 9, 42-54.

35. Malik, A. Creating competitive advantage through source basic capital strategic humanity in the industrial age 4.0. Int. Res. J. Adv. Eng. Sci. 2019, 4, 209-215.

36. Tong, Y.; Lei, S. War of position and micro blogging in China. J. Contemp. China 2013, 22, 292-311. [CrossRef]

37. Anggraeni, R.; Wijaya, E. Pengantar mengenai Hegemoni dan Hukum: Menyoal Kembali Bekerjanya Hukum di Masyarakat. J. Magister Huk. Udayana 2019, 8, 494-511. [CrossRef]

38. Rudner, J.; Shahani, F.; Hogan, T. Islamic Architectures of Self-Inclusion and Assurance in a Multicultural Society. Fabrications 2020, 30, 153-175. [CrossRef]

39. Magu, S. Reconceptualizing cultural globalization: Connecting the "cultural global" and the "cultural local". Soc. Sci. 2015, 4, 630-645. [CrossRef]

40. Astadahla, I.W.B. Aplikasi Multimedia Interaktif Pengenalan Drama Gong Wijayakesuma Abianbase Kabupaten Gianyar Berbasis Mobile. Available online: https:/ / onesearch.id/Record/IOS617.article-296. (accessed on 21 March 2019).

41. Yun, J.J.; Zhao, X.; Jung, K.; Yigitcanlar, T. The Culture for Open Innovation Dynamics. Sustainability 2020, 12, 5076. [CrossRef]

42. Lee, M.; Yun, J.J.; Pyka, A.; Won, D.; Kodama, F.; Schiuma, G.; Zhao, X. How to respond to the fourth industrial revolution, or the second information technology revolution? Dynamic new combinations between technology, market, and society through open innovation. J. Open Innov. Technol. Mark. Complex. 2018, 4, 21. [CrossRef]

43. McKean, P.F. 6. Towards a Theoretical Analysis of Tourism: Economic Dualism and Cultural Involution in Bali. In Hosts and Guests; University of Pennsylvania Press: New York, NY, USA, 2012.

44. Ni Made, R.; Komang, S.I.; Gede, Y.I. Model of Innovative Wayang Wong for Millenial Generation to Meet 4.0 Industrial Revolution Era in Bali. J. Environ. Treat. Tech. 2020, 8, 999-1004.

45. Hariman, R.; Lucaites, J.L. No Caption Needed: Iconic Photographs, Public Culture, and Liberal Democracy; University of Chicago Press: London, UK, 2007.

46. Kurtz, D.V. Hegemony and anthropology: Gramsci, exegeses, reinterpretations. Crit. Anthropol. 1996, 16, 103-135. [CrossRef]

47. Triangulation, D.S. The use of triangulation in qualitative research. Oncol. Nurs. Forum 2014, 41, 545.

48. Eco, U. A Theory of Semiotics; Indiana University Press: Bloomington, Indiana, 1979.

49. Searle, J.R. Semiotics as a Theory of Representation. Theory Crit. Soc. Regul. 2020, 1, 49-58.

50. Bsharat, T.R.; Barahmeh, M.Y. The Influence of Applying Educational Active Drama in Enhancing Speaking Skills in TeachingLearning English Language: A Theoretical Response. Tech. Soc. Sci. J. 2020, 14, 10.

51. Atmadja, N.B. Bali in the Era of Globalization: The Island of a Thousand Temples Is Not as Beautiful as It Looks. Research Results-Case Studies in Various Villages; Kajian Bali: Singaraja, Bali, 2005.

52. Satyawati, M.S.; Kardana, I.N.; Rajistha, I. Figurative Language in Balinese Based On Social Praxis Analysis. Talent Dev. Excell. 2020, 12, 2.

53. Evans, W. Counter-Hegemony at Work: Resistance, Contradiction and Emergent Culture inside a Worker-Occupied Hotel. Berkeley J. Sociol. 2007, 51, 33-68.

54. Aaltonen, S. Time-Sharing on Stage: Drama Translation in Theatre and Society; Multilingual Matters Ltd.: Tonawanda, NY, USA, 2000.

55. Lech, K. Dramaturgy of Form: Performing Verse in Contemporary Theatre, 1st ed.; Routledge: London, UK, 2021.

56. Setini, M.; Yasa, N.N.K.; Gede Supartha, I.W.; Ketut Giantari, I.; Rajiani, I. The passway of women entrepreneurship: Starting from social capital with open innovation, through to knowledge sharing and innovative performance. J. Open Innov. Technol. Mark. Complex. 2020, 6, 25. [CrossRef]

57. Ruastiti, N.M.; Sudirga, I.K.; Yudarta, I.G. The Appreciation of the Innovative Wayan Wong Performance Arts through Digital Media. Psychol. Educ. J. 2020, 58, 5241-5252.

58. Homayoun, S.; Henriksen, D. Creativity in business education: A review of creative self-belief theories and arts-based methods. J. Open Innov. Technol. Mark. Complex. 2018, 4, 55. [CrossRef]

59. Xiaojuan, J.; Libin, L. Globalization of Services in the Internet Age: A New Engine, Acceleration and Major Power Competitiveness. Soc. Sci. China 2020, 41, 5-23. [CrossRef]

60. Picard, M. “Cultural Tourism” in Bali: Cultural Performances as Tourist Attraction. Indonesia 1990, 49, 37-74. [CrossRef] 
61. Primayana, K.H. The Implementation of School Management Based On the Values of Local Wisdom Tri Hita Karana and Spiritual Intelligence on Teacher Organizational Commitments. 2019. Available online: https://stahnmpukuturan.ac.id/jurnal/index. $\mathrm{php} / \mathrm{ichecy} /$ article/view/134 (accessed on 21 March 2019).

62. Roth, D.; Sedana, G. Reframing Tri Hita Karana: From 'Balinese Culture'to Politics. Asia Pac. J. Anthropol. 2015, 16, 157-175. [CrossRef]

63. Barth, F. The analysis of culture in complex societies. Ethnos 1989, 54, 120-142. [CrossRef]

64. Redding, D.J. Performing Arts, Identity, and the Construction of Place in Three Balinese Transmigration Settlements; University of Hawai'i at Manoa: Rice, Timothy, 2002.

65. Liswahyuningsih, N.L.G.; Bal, I.P. Semantics Analysis of Pronoun I and You in Balinese Language. Int. J. Res. Soc. Sci. 2015, 5, 518-531.

66. Kramer, C. Parrhesia, Humor, and Resistance. 2020. Available online: https://philpapers.org/rec/KRAPHA-2 (accessed on 22 March 2020).

67. Smith, J.L. Melodrama; Taylor \& Francis: New York, NY, USA, 2017.

68. Dewi, N.P.C.P. Pendidikan Karakter Berbasis Kearifan Lokal Melalui Nangun Sat Kerthi Loka Bali. Widyacarya J. Pendidik. Agama Budaya. 2020, 4, 24-32.

69. Tan, S.K.; Lim, H.H.; Tan, S.H.; Kok, Y.S. A cultural creativity framework for the sustainability of intangible cultural heritage. J. Hosp. Tour. Res. 2020, 44, 439-471. [CrossRef]

70. Alvermann, D.E.; Hagood, M.C. Critical media literacy: Research, theory, and practice in “New Times”. J. Educ. Res. 2000, 93, 193-205. [CrossRef]

71. Fan, K.K.; Zhou, Y. The Influence of Traditional Cultural Resources (TCRs) on the Communication of Clothing Brands. Sustainability 2020, 12, 2379. [CrossRef]

72. Suwana, F. Content, changers, community and collaboration: Expanding digital media literacy initiatives. Media Pract. Educ. 2021, 1-18. [CrossRef]

73. Muhamad, M.; Ruslanjari, D.; Hanif, A. Creative Tourism in the Era of New Normality in the Advancement of Culture. E-J. Tour 2021, 125-132. [CrossRef]

74. Yoedtadi, M.G.; Pribadi, M.A. Alternative Media as Counter-Hegemony: A Case study of Konde. co and Magdalene. co. In Proceedings of the 2nd Tarumanagara International Conference on the Applications of Social Sciences and Humanities (TICASH 2020); Atlantis Press: Paris, France, 2020; pp. 99-107. [CrossRef]

75. Balipost. Drama Gong, Elegant Theater. Available online: https://www.balipost.com/news/2020/06/25/131825/Drama-Gong, Teater-yang-Elegan.html/ (accessed on 21 March 2021).

76. Desaseni. Indonesian Contemporary Art Is ... . . . Available online: https://www.desaseni.com/indonesian-contemporary-artis/ (accessed on 21 March 2021).

77. Denpasarkota. Drama Gong Is Back on Its Feet, the People are Happy Again. Available online: https:/ / www.denpasarkota.go id/berita/baca/7994\#! (accessed on 22 March 2021). 